\title{
The Stability of Roadway Groups under Rheology Coupling Mining Disturbance
}

\author{
Sen Yang ${ }^{1,2}$, Guichen $\mathrm{Li}^{1,2, *}$, Ruiyang $\mathrm{Bi}^{3}$, Bicheng Yao ${ }^{1,2}$, Ruiguang Feng ${ }^{1,2}$ and Yuantian Sun ${ }^{1,2}$ \\ 1 School of Mines, China University of Mining and Technology, Xuzhou 221116, China; \\ ts20020064a31tm@cumt.edu.cn (S.Y.); ts20020178p21@cumt.edu.cn (B.Y.); ts20020100p21@cumt.edu.cn (R.F.); \\ yuantiansun@cumt.edu.cn (Y.S.) \\ 2 Key Laboratory of Deep Coal Resource Mining of the Ministry of Education, University of Mining and \\ Technology, Xuzhou 221116, China \\ 3 School of Resources and Safety Engineering, Central South University, Changsha 410083, China; \\ biruiyang@csu.edu.cn \\ * Correspondence: liguichen@cumt.edu.cn; Tel.: +86-1580-521-5566
}

Citation: Yang, S.; Li, G.; Bi, R.; Yao, B.; Feng, R.; Sun, Y. The Stability of Roadway Groups under Rheology Coupling Mining Disturbance. Sustainability 2021, 13, 12300 . https://doi.org/10.3390/su132112300

Academic Editor: Giovanna

Pappalardo

Received: 2 October 2021

Accepted: 3 November 2021

Published: 8 November 2021

Publisher's Note: MDPI stays neutral with regard to jurisdictional claims in published maps and institutional affiliations.

Copyright: (c) 2021 by the authors. Licensee MDPI, Basel, Switzerland. This article is an open access article distributed under the terms and conditions of the Creative Commons Attribution (CC BY) license (https:// creativecommons.org/licenses/by/ $4.0 /)$.

\begin{abstract}
The deep roadway groups play an important role in transportation and ventilation in coal mine production. Therefore, it is very important to comprehensively analyze the coupling effect of rheological deformation and coal mining on the stability of the roadway groups. In this paper, the disturbance effects of different stop-mining lines on roadway groups under long-term rheology were investigated by numerical simulation, and the failure mechanism of roadway groups with large sections and multiple disturbances in a deep well was revealed. The results show that the long working face will lead to the collapse of key strata, and the influence range will spread to the adjacent roadway groups. When the distance between the working face and the stop-mining line is $100 \mathrm{~m}$, the roadway groups cannot be affected by the working face mining, and the reserved width of the coal pillar can be determined to be $100 \mathrm{~m}$, which increases the stability of the roadway's surrounding rock and maintains the mine safety production. This paper aims to provide a reference for groups design and control under similar conditions.
\end{abstract}

Keywords: rheological deformation; key stratum; roadway groups; roadway deformation; surrounding rock control

\section{Introduction}

In recent years, with the continuous increase in mining intensity and depth, a large number of difficult-to-support roadways have appeared, such as roadways with high stress, strong mining-affected roadways, roadways with extremely broken surrounding rocks, and roadways with extra-large cross-sections. Under the influence of factors such as tectonic stress, strong mining, faults, etc., roadway section shrinkage is serious, surrounding rock fragmentation is high, the floor experiences heave, and supporting components fail frequently, which increases the intensity and frequency of roadway repair [1]. Therefore, the stability of the deep roadway groups is essential for safe and efficient production.

For deep roadways, the ground stress of the environment in which the roadway is located increases. Under the action of high ground stress, rheological deformation occurs in the deep roadway [2,3]. The deformation of the deep soft rock roadway includes the deformation during the roadway excavation, the rheological deformation of the roadway during the service production period, and the deformation caused by other factors such as support failure and stress disturbance. The theory and technology of group control, originally applicable to shallow parts, cannot meet the requirements of the control effect in the deep part [4]. For the control of coal roadways with rheological properties, the theory and technology of soft rock support can be used for reference [5-9]. For soft rock roadways, many deep soft rock roadway control technologies have been produced on the basis of 
clarifying the damage influence range of surrounding rock, such as the combined support technology of high prestressed bolt primary support and cable reinforcement, bolt-grouting combined support technology, and high-efficiency jet grouting (JG) techniques, etc. [10-18]. In the middle and late 20th century, Austrian engineers put forward the basic theory of deep roadway surrounding rock control; a new Austrian tunnelling method based on predecessors. Previous researchers [19-21] have conducted exploratory research on the advanced support technology of rheological roadways, and have achieved fruitful results. The shape of the underground roadway is irregular, and the positional relationship of the roadway group is complicated, coupled with deep in-situ stress, which results in greater complexity. A large number of researchers chose to use numerical simulation combined with field cases to conduct research, and summarized the rheological deformation laws of different positions of the roadway, including the side part, roof and floor, and the obtained data from the roadway's surrounding rock deformation are closer to the actual field [22-25].

During deep mining, the appearance of rock pressure caused by rock movement has become increasingly serious. When mining coal seams, it will cause the redistribution of coal and rock mass stress and form a new mining stress field [26-28], which will affect roadway support and other projects. In the deep mine roadway, the main roadway with a long service life forms the roadway groups. These roadways are relatively close to each other, and the disturbance effect is large, which causes serious fragmentation and instability of the rock surrounding the roadway [29-31]. A number of researchers [32-35] have conducted exploratory research on the new technology of roadway deformation control and support, and made great progress. Aiming at the disturbance of mining to roadways, researchers have conducted a lot of work, analyzed the damage and movement law of the overburden structure of coal roadway under the influence of mining, and mastered the influence range after mining [36-39].

The deep mine roadway groups are continuously affected by the superposition of rheological deformation and coal and rock mining. At present, there are few research results of a comprehensive analysis of mining and rheology on roadway stability. Because of this situation, this paper intends to comprehensively explore its impact on roadway stability from the two dimensions of mining and rheology, to increase the stability of roadway surrounding rock and maintain mine safety production.

\section{Project Overview}

Jining No. 2 Coal Mine is located in Jining City, China. The coal seam mined belongs to Jining Coal Field, with an area of approximately 87.1 square kilometers. Its geographic location is shown in Figure 1.

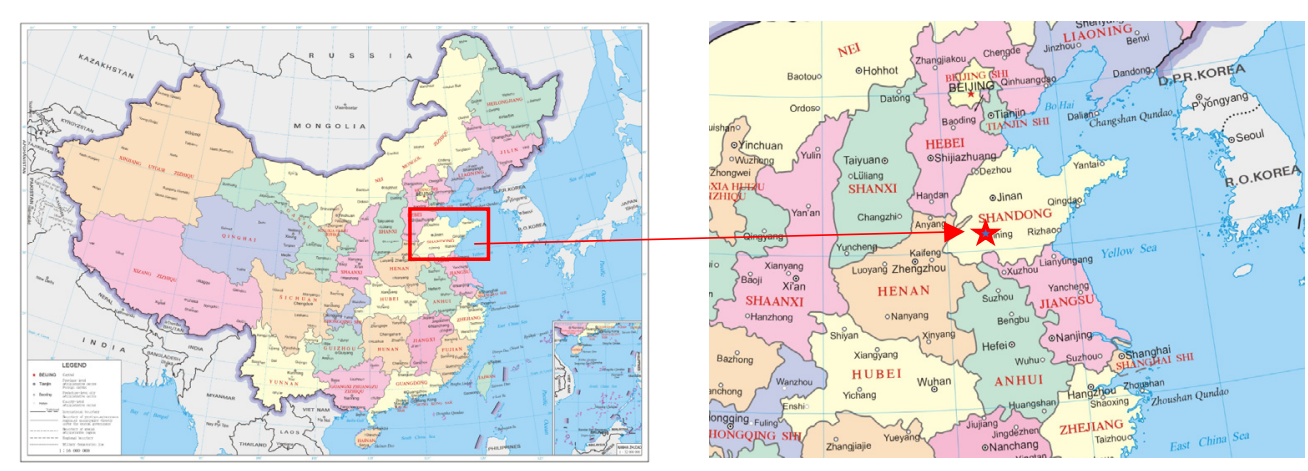

Figure 1. Geographical location map of Jining No. 2 Coal Mine.

The three lower coal seams were mined at the 11th district of the No. 2 Mine of Yankuang Groups, with a coal thickness of 3.6 to $4.8 \mathrm{~m}$, with an average of $4.13 \mathrm{~m}$. The direct roof is medium sandstone with a thickness of 7.6 9.95 $\mathrm{m}$ and an average thickness of $8.78 \mathrm{~m}$. The main roof is siltstone with a thickness of $6.1 \sim 9.2 \mathrm{~m}$ and an average thickness of $7.65 \mathrm{~m}$. The floor is mudstone with a thickness of $1.5-3.0 \mathrm{~m}$ and an average thickness of 
$2.2 \mathrm{~m}$. The generalized stratigraphic column and the character description of Jining No. 2 Coal Mine is shown in Figure 2.

\begin{tabular}{|c|c|c|c|c|}
\hline $\begin{array}{l}\text { Thickness } \\
/ \mathrm{m}\end{array}$ & Columnar & Lithology & $\begin{array}{c}\text { Buried depth } \\
/ \mathrm{m}\end{array}$ & Description \\
\hline$\frac{3.24 \sim 5.3}{4.27}$ & & $\begin{array}{l}\text { Fine-grained } \\
\text { sandstone }\end{array}$ & 742.69 & $\begin{array}{l}\text { Grayish white, mainly composed of quartz } \\
\text { and feldspar, with horizontal bedding. }\end{array}$ \\
\hline$\frac{6.3 \sim 7.2}{6.75}$ & & $\begin{array}{l}\text { Medium } \\
\text { sandstone }\end{array}$ & 749.44 & $\begin{array}{l}\text { Grayish white, mainly composed of quartz } \\
\text { and feldspar, with hard lithology. }\end{array}$ \\
\hline$\frac{6.1 \sim 9.2}{7.65}$ & & Siltstone & 757.09 & $\begin{array}{l}\text { Dark gray, massive, with well-developed } \\
\text { fissures. }\end{array}$ \\
\hline$\frac{7.6 \sim 9.95}{8.78}$ & & $\begin{array}{l}\text { Medium } \\
\text { sandstone }\end{array}$ & 765.87 & $\begin{array}{l}\text { Grayish white, mainly composed of quartz } \\
\text { and feldspar, with hard lithology. }\end{array}$ \\
\hline$\frac{3.6 \sim 4.8}{4.13}$ & & Coal & 770.0 & $\begin{array}{l}\text { Black, mainly bright coal, partially } \\
\text { containing } 0.2 \mathrm{~m} \text { gangue. }\end{array}$ \\
\hline$\frac{1.5 \sim 3.0}{2.2}$ & & Mudstone & 772.2 & $\begin{array}{l}\text { Gray-black, with plant root fossils, with } \\
\text { swelling properties. }\end{array}$ \\
\hline$\frac{4.1 \sim 6.3}{5.5}$ & & Siltstone & 777.7 & $\begin{array}{l}\text { Grayish white, mainly composed of quartz } \\
\text { and feldspar, with horizontal bedding. }\end{array}$ \\
\hline$\frac{3.3 \sim 9.0}{6.2}$ & & $\begin{array}{l}\text { Fine-grained } \\
\text { sandstone }\end{array}$ & 783.9 & $\begin{array}{l}\text { Grayish white, mainly composed of quartz } \\
\text { and feldspar, with horizontal bedding. }\end{array}$ \\
\hline$\frac{9.7 \sim 15.2}{13.1}$ & 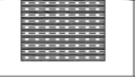 & $\begin{array}{l}\text { Fine } \\
\text { siltstone }\end{array}$ & 797.0 & $\begin{array}{l}\text { Gray-black, with a small amount of pyrite } \\
\text { particles, with slightly developed cracks. }\end{array}$ \\
\hline
\end{tabular}

Figure 2. Generalized stratigraphic column.

\subsection{Position Relationship between Working Face and Roadway}

Figure 3 shows the distribution of four main roadways and working faces at $-740 \mathrm{lev}$ els in the south wing of Jining No. 2 Coal Mine of Yankuang Groups. The elevation of the track roadway is $-740 \mathrm{~m}$, the elevation of the ventilation roadway is $-732 \mathrm{~m}$, the elevation of the belt conveyor roadway is $-738 \mathrm{~m}$, and the elevation of the auxiliary transport roadway is $-738 \mathrm{~m}$. The horizontal distance between the track roadway and the ventilation roadway is $30 \mathrm{~m}$, the horizontal distance between the ventilation roadway and the belt conveyor roadway is $30 \mathrm{~m}$, and the horizontal distance between the belt conveyor roadway and the auxiliary transport roadway is $50 \mathrm{~m}$. The track roadway, belt conveyor roadway, and auxiliary transport roadway are all excavated in the rock, and the ventilation roadway is in the coal seam.

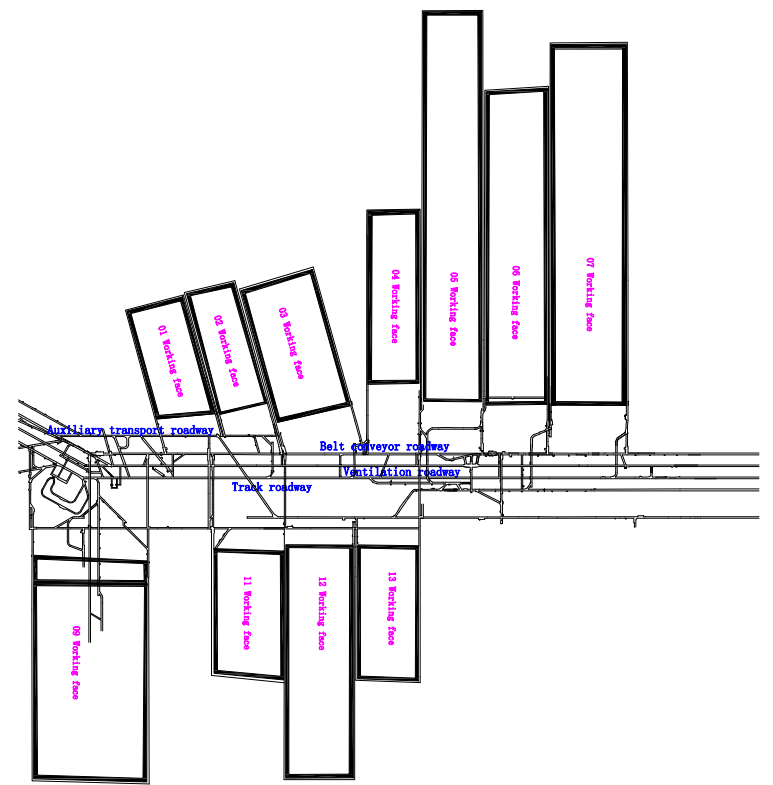

Figure 3. Roadway location distribution map. 


\subsection{The Influence of Working Face Rheological Coupling Mining on Roadway Stability}

The mining level where the roadway is located has a large buried depth and high stress The vertical ground stress of the $-740 \mathrm{~m}$ roadway reaches $19.45 \mathrm{MPa}$ (the ground elevation is $+38 \mathrm{~m}$ ), which is a deep-well high-stress roadway. After the excavation of the roadway is completed, under the action of high ground stress, the surrounding rock stress is continuously adjusted over time, and the roadway undergoes rheological deformation, which causes the roadway to gain instable characteristics, such as bolt failure, roof subsidence, and floor heave.

The thickness of the coal seam in the mining area is as high as $5 \sim 6 \mathrm{~m}$. When the working face is close to the main roadway, the stress area is large. The average horizontal distance between the four main roadways at the $-740 \mathrm{~m}$ level is $30 \mathrm{~m}$, and the stopping line is only about $40 \mathrm{~m}$ away from the nearest roadway. Therefore, the main roadway is affected by multiple strong mining operations, which makes it difficult to control the surrounding rock of the roadway.

There are four main roadways with large deformations and a large roadway span, averaging more than $4.5 \mathrm{~m}$. The length of the supporting bolt adopted is only $2.4 \mathrm{~m}$, and the effective length is $2.3 \mathrm{~m}$. Theoretically, it cannot form an effective supporting structure, and it is difficult to reflect the effect of active support. The roof spray strata cracked severely, floor heave was serious, there was a roof fall phenomenon, the falling height was $3 \mathrm{~m}$, and the length was $6.7 \mathrm{~m}$. Recently, roadway's surrounding rock deformation is serious, roadway maintenance workload is large, and safety guarantee is low. The partial destruction of the roadway is shown in Figure 4.

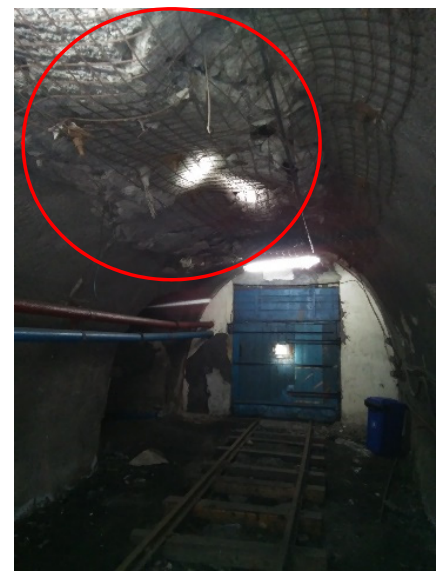

(a)

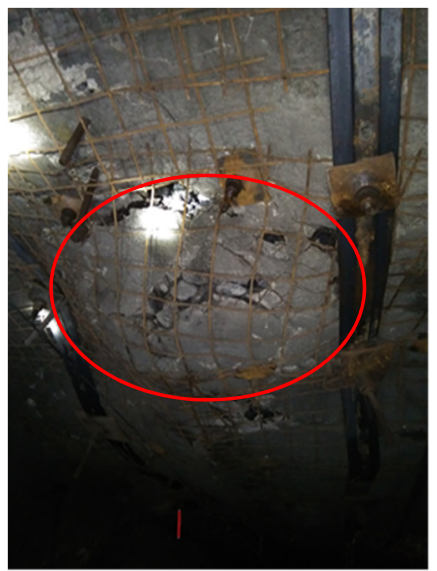

(b)

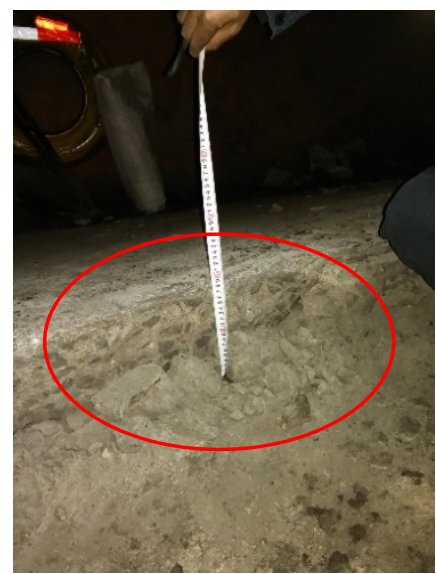

(c)

Figure 4. Damage of roadway. (a) Anchor failure, (b) Roof subsidence, (c) Floor heave.

Several drill boreholes were drilled in the belt conveyor roadway, the track roadway, the ventilation roadway, and the auxiliary transportation roadway, respectively, for monitoring. The roadway groups facing the 01 and 10 working faces are used as test sections. In specific steps, three boreholes are set up in each of the four main roadways, each with an interval of $50 \mathrm{~m}$, and the drilling positions are located in the middle of the roof of the roadway and on both shoulders. The hole diameter is $32 \mathrm{~mm}$ and the depth is $10 \mathrm{~m}$. Among them, the monitoring drill view of the track roadway is shown in Figure 5. The mudstone is severely broken in the deep part of the borehole, is moderately broken in the coal seam, and the surrounding rock is intact in the middle sandstone part. 


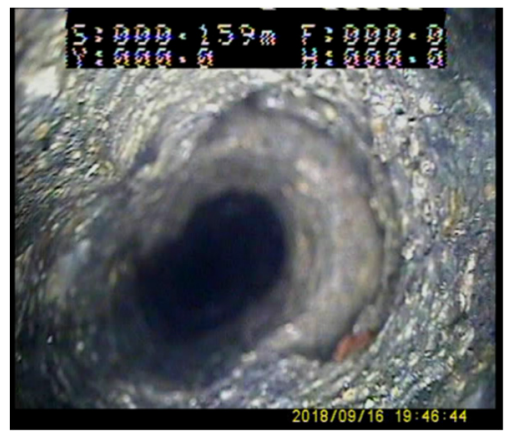

(a)

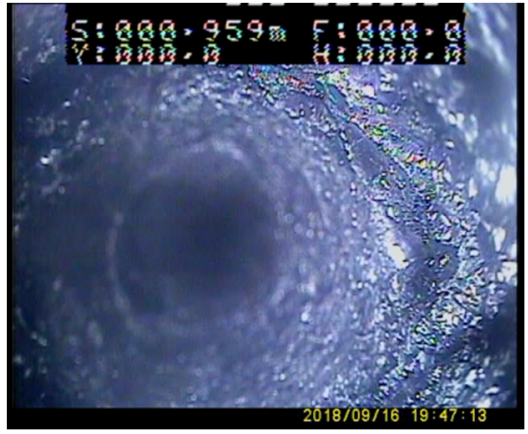

(b)

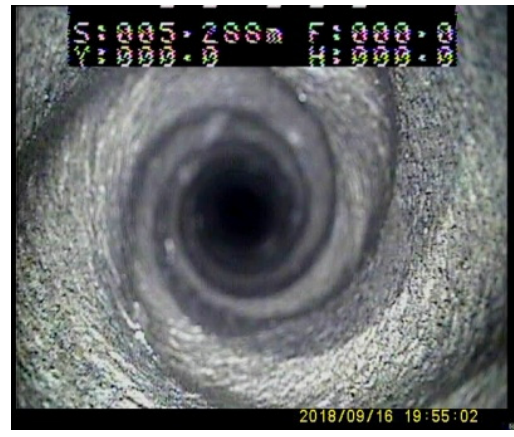

(c)

Figure 5. Peeking observation results of the roadway boreholes.(a) Mudstone, badly fractured, (b) Coal seam, medium crushing, (c) Medium sandstone, complete surrounding rock.

\section{Establishment of a Numerical Simulation Model for Disturbance Effect of Roadway Groups in a Deep Well}

Through on-site measurements and theoretical analysis, the cause of the instability of the surrounding rock in the $-740 \mathrm{~m}$ horizontal roadway groups in Jining No. 2 Mine is obtained. Further, through the combination of theoretical analysis and numerical simulation, the instability mechanism of the roadway groups is revealed. Using Flac3D finite element numerical simulation software, by simulating the distance from different stop-mining lines to the roadway groups, the optimal stop-mining line position is determined. The supporting system of the surrounding rock under the influence of deep roadway groups disturbance is obtained.

\subsection{Numerical Simulation Modeling Process}

Taking the $-740 \mathrm{~m}$ horizontal roadway groups in the south wing of Jining No. 2 Mine as the research object, the 100-200 m roadway is taken as the test section within the roadway range of the 01 and 10 working faces. The CVISC rheological model is adopted for the roadway $[40,41]$. The model works by simulating the mutual influence law of the full excavation of the roadway, and the influence of the two wings' working faces on the test section roadway during the mining process. It then analyzes the damage of the roadway and provides a theoretical basis for later determining the roadway support parameters. Moreover, it guides the determination of the stop-mining line at the working face. The model has a length of $529.4 \mathrm{~m}$, a height of $140 \mathrm{~m}$, and a width of $30 \mathrm{~m}$. It contains a total of 9 rock strata. A load of $17.5 \mathrm{MPa}$ is applied to the top of the model to simulate the pressure of the overburden. Boundary conditions are imposed on the model, and the left and right horizontal displacement of the model is limited to within $\pm 0.1 \mathrm{~m}$, and the bottom vertical displacement is limited to within $\pm 0.1 \mathrm{~m}$. The simplified boundary model is shown in Figure 6. The track roadway is arched with a width of $5.0 \mathrm{~m}$ and a clear height of $4.0 \mathrm{~m}$. The belt conveyor roadway is arched with a width of $5.0 \mathrm{~m}$ and a clear height of $4.8 \mathrm{~m}$. The ventilation roadway is rectangular, with a width of $4.6 \mathrm{~m}$ and a clear height of $3.3 \mathrm{~m}$. The 
auxiliary transportation roadway is rectangular, with a width of $4.8 \mathrm{~m}$ and a clear height of $3.2 \mathrm{~m}$. Since the inclination angle of the coal seam is only $2^{\circ} \sim 10^{\circ}$, with an average of $5^{\circ}$, it is a nearly horizontal coal seam, and the test section roadway is only $100 \sim 200 \mathrm{~m}$. Within this range, coal seams and rock strata can be regarded as horizontal rock strata. The rock mechanics parameters are shown in Table 1. Rheological parameters are shown in Table 2.

Gritstone

Fine-grained sandstone Medium sandstone Siltstone

Medium sandstone Coal

Mudstone

Siltstone

Fine-grained sandstone

Fine siltstone

Gritstone

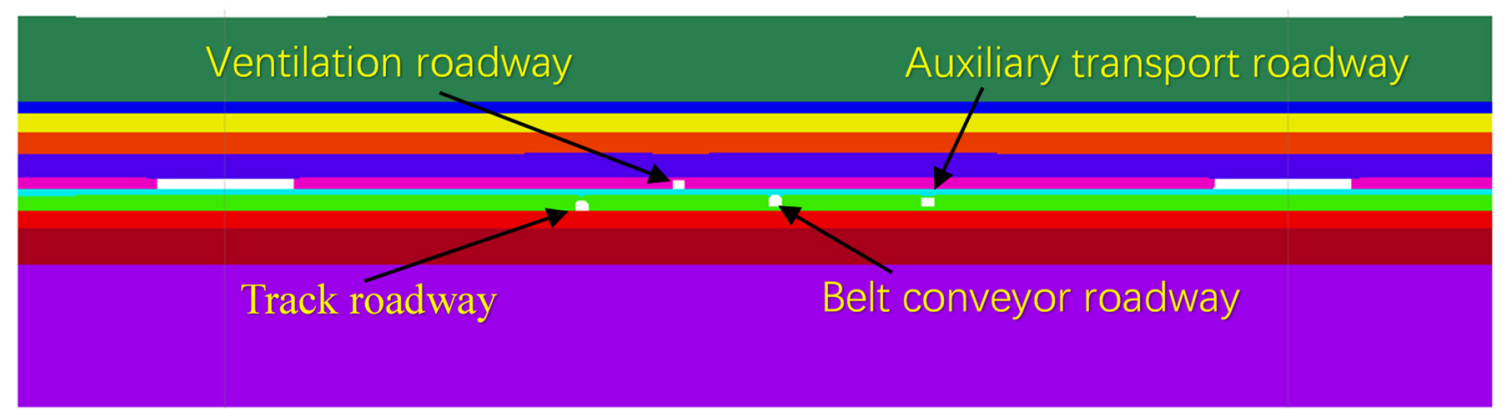

Figure 6. Model diagram.

Table 1. Physical and mechanical parameters of rock and coal in numerical simulations.

\begin{tabular}{|c|c|c|c|c|c|c|}
\hline Lithology & Density $\mathrm{kg} / \mathrm{m}^{3}$ & $\begin{array}{c}\text { Bulk } \\
\text { Modulus/GPa }\end{array}$ & $\begin{array}{c}\text { Shear } \\
\text { Modulus/GPa }\end{array}$ & Cohesion/MPa & $\begin{array}{l}\text { Friction } \\
\text { Angle }^{\circ}\end{array}$ & $\begin{array}{c}\text { Tensile } \\
\text { Strength/MPa }\end{array}$ \\
\hline Gritstone & 2450 & 34.37 & 24.71 & 9.81 & 45 & 10.51 \\
\hline $\begin{array}{l}\text { Fine grained } \\
\text { sandstone }\end{array}$ & 2600 & 21.7 & 15.6 & 5.72 & 38 & 7.44 \\
\hline $\begin{array}{l}\text { Medium } \\
\text { sandstone }\end{array}$ & 2550 & 30.14 & 21.67 & 7.30 & 41 & 8.21 \\
\hline Siltstone & 2650 & 17.47 & 12.56 & 4.12 & 32 & 2.94 \\
\hline Coal & 1450 & 0.55 & 0.33 & 2.45 & 22 & 0.24 \\
\hline Mudstone & 2250 & 7.11 & 3.86 & 3.43 & 35 & 0.98 \\
\hline Fine siltstone & 2620 & 19.00 & 14.08 & 4.92 & 34 & 5.19 \\
\hline
\end{tabular}

Table 2. Parameters of the rheological model in numerical simulation.

\begin{tabular}{cccc}
\hline $\mathrm{G}_{\mathbf{K}} / \mathbf{P a}$ & $\mathrm{G}_{\mathbf{M}} / \mathbf{P a}$ & $\mathbf{N}_{\mathbf{K}} /$ Pa.s & $\mathbf{N}_{\mathbf{M}} /$ Pa.s \\
\hline $1.38 \times 10^{8}$ & $2.2 \times 10^{8}$ & $2 \times 10^{18}$ & $15 \times 10^{15}$ \\
\hline
\end{tabular}

\subsection{Numerical Simulation Scheme}

After the model stress is balanced, the four main roadways are first driven. In the process of excavating a group of roadways (distance $30 \sim 50 \mathrm{~m}$ ), the stress redistributes after the roadway is excavated, and there is a mutual influence between the roadways. The mutual disturbance between the roadways increases the difficulty of controlling the surrounding rock of the roadways. By observing and analyzing the stress distribution, displacement distribution, and plastic zone distribution of the surrounding rock of the roadway after 2 years of rheological deformation, it can be judged whether there is a mutual disturbance in the roadway groups.

During the advancing process of the working face in the test section, it is affected by the disturbance of the 01 and 10 working faces, which belong to the multi-disturbed roadway. The study of the influence of the working face on the surrounding rock of the roadway during the mining process is of great significance to determine the stop line position. According to the actual situation, there should be a wait for the roadway rheology for two years before simulating the mining process of the working face. The simulation analyzes the distribution law of the stress field, displacement field, and plastic zone within the model range under the three scenarios of the stopping mining line of $50 \mathrm{~m}, 75 \mathrm{~m}$, and $100 \mathrm{~m}$, to obtain the best stopping line position through simulation. 


\section{Results and Discussion on Coupling Disturbance of Rheology and Mining in Deep Mine Roadway Groups}

\subsection{Influence of Rheological Disturbance during Roadway Excavation}

In this section, by observing and analyzing the stress distribution, displacement distribution, and plastic zone distribution of the surrounding rock of the roadway after 2 years of rheological deformation, it can be judged whether there is a mutual disturbance in the roadway groups.

The vertical stress distribution of the surrounding rock in the roadway groups after 2 years of rheology is shown in Figure 7. It can be seen from the figure that for the four main roadways at the level of $-740 \mathrm{~m}$ in the south wing, there is a slight difference between the track roadway, the ventilation roadway, and the belt conveyor roadway. There is no mutual disturbance between the belt conveyor roadway and the auxiliary transport roadway.

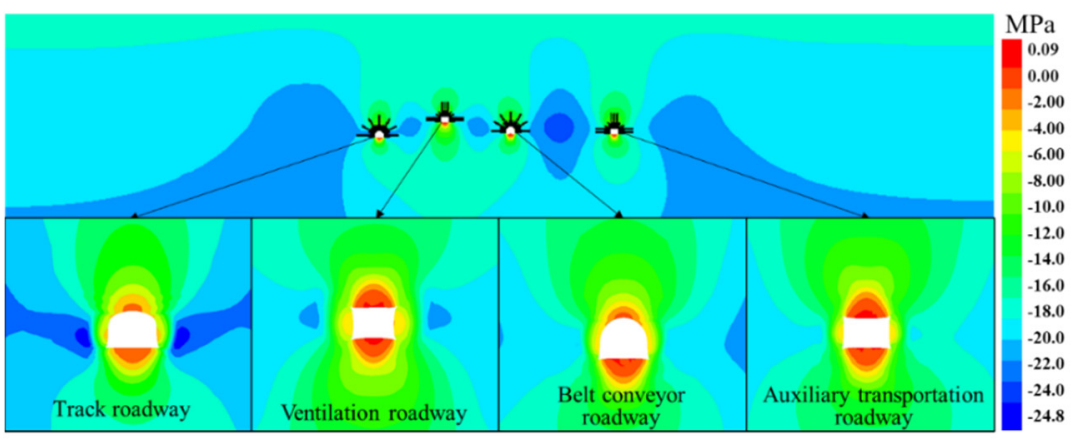

Figure 7. Vertical stress distribution of surrounding rock of roadway groups.

The surrounding rock displacement of the roadway groups after 2 years of rheological deformation is shown in Figure 8. It can be seen from the figure that after the roadway group is mined, the maximum deformation of the surrounding rock of the roadway is about $430 \mathrm{~mm}$ under the conditions of the design support parameters. Under this condition, the expansion of brush repair can realize the control of the deformation of the surrounding rock of the roadway.

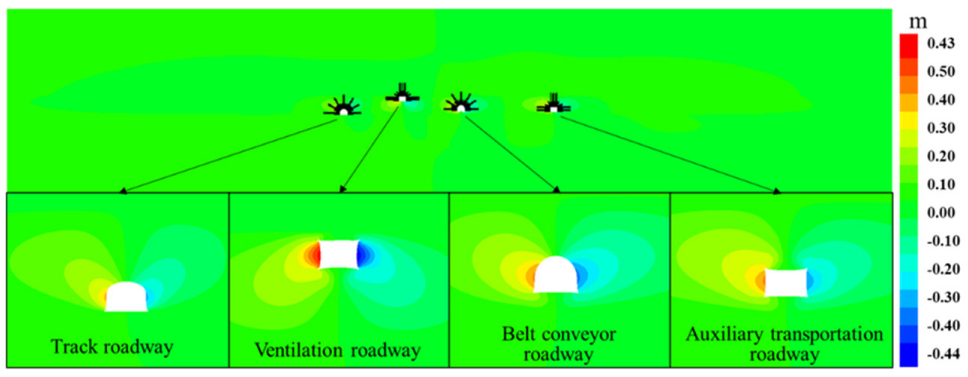

(a)

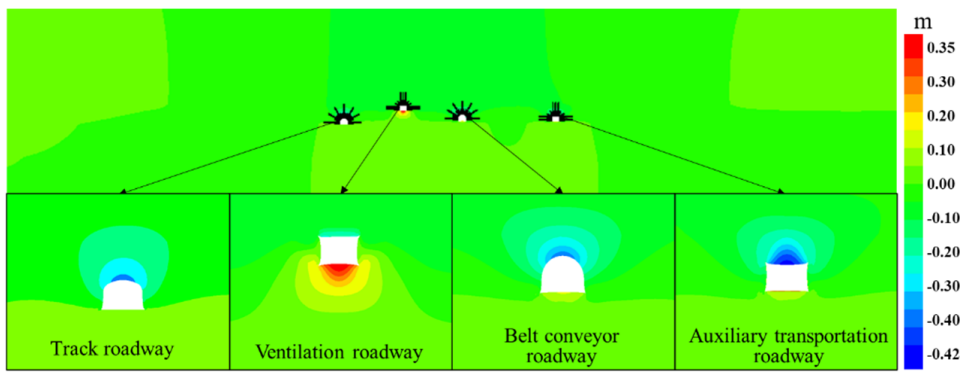

(b)

Figure 8. Displacement cloud map of surrounding rock behind the excavation roadway groups. (a) Deformation of the two sides of the roadway, (b) Deformation of roof and floor of roadway. 
The plastic zone distribution of the surrounding rock of the roadway after 2 years of rheological deformation is shown in Figure 9. It can be seen from the figure that after 2 years of rheological deformation after roadway excavation, the surrounding rock of the roadway has plastic deformation under the condition of stress concentration. For the deep roadway groups, the surrounding rock of the roadway has a different distribution of plastic zone under different rock strata conditions. Among them, the plastic zone of the roof and floor of the auxiliary transportation roadway is larger. Among them, the roof and floor of the ventilation roadway have a larger plastic zone. The depth of the floor plastic zone is about $4.2 \mathrm{~m}$, and the plastic failure range is large, which is difficult for roadway control. In the subsequent roadway treatment process, it is necessary to ensure the quality of the roadway roof support and ensure the stability of the surrounding rock's roof. For the four roadways studied, the failure range of the roof and floor plastic zone is about $2-4.2 \mathrm{~m}$.

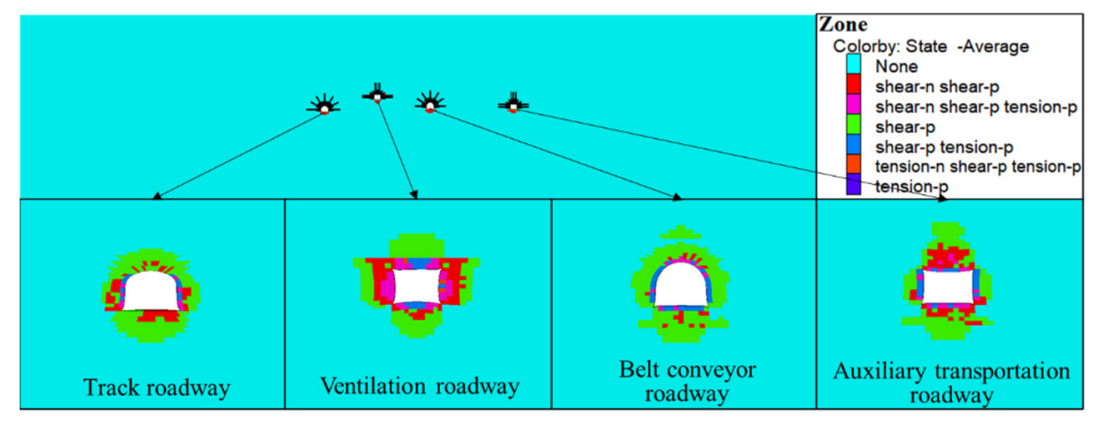

Figure 9. Distribution of plastic zone after roadway groups excavation.

\subsection{The Influence of Rheological Coupling Mining of Working Face on Stress Disturbance of Roadway Groups}

A total of two years after the roadway was rheologically deformed, coal mining began at the working face. The vertical stress distribution of the surrounding rock of the model is shown in Figure 10. It can be seen from the figure that mining has disturbance effects on the four main roadways. When the distance between the working face and the roadway is $50 \mathrm{~m}$, the disturbance effect of the track roadway and auxiliary transport roadway is the most severe. When the distance between the working face and the roadway is $75 \mathrm{~m}$, the impact of the mining on the disturbance of the track roadway and auxiliary transport roadway is reduced. When the distance between the working face and the roadway is $100 \mathrm{~m}$, the impact of the mining on the roadway groups disturbance is minimal.

When the distance between the working face and the roadway is $50 \mathrm{~m}, 75 \mathrm{~m}$, and $100 \mathrm{~m}$, the maximum vertical stress of the surrounding rock of the roadway is shown in Figure 11. After the excavation of the roadway groups, the maximum vertical stress on the left and right sides of the track roadway is $24.2 \mathrm{MPa}$, and the maximum vertical stress on the two sides of the auxiliary transport roadway is $20.6 \mathrm{MPa}$ and $22.1 \mathrm{MPa}$, respectively. After the coal seam is mined, the maximum vertical stress on both sides of the roadway is increased. When the distance of the stopping line increases from $50 \mathrm{~m}$ to $100 \mathrm{~m}$, the maximum vertical stress of the two sides of the track roadway and auxiliary transport roadway decreases gradually. When the distance between the stopping line and the roadway is $100 \mathrm{~m}$, the change rate of the maximum vertical stress is the smallest. 


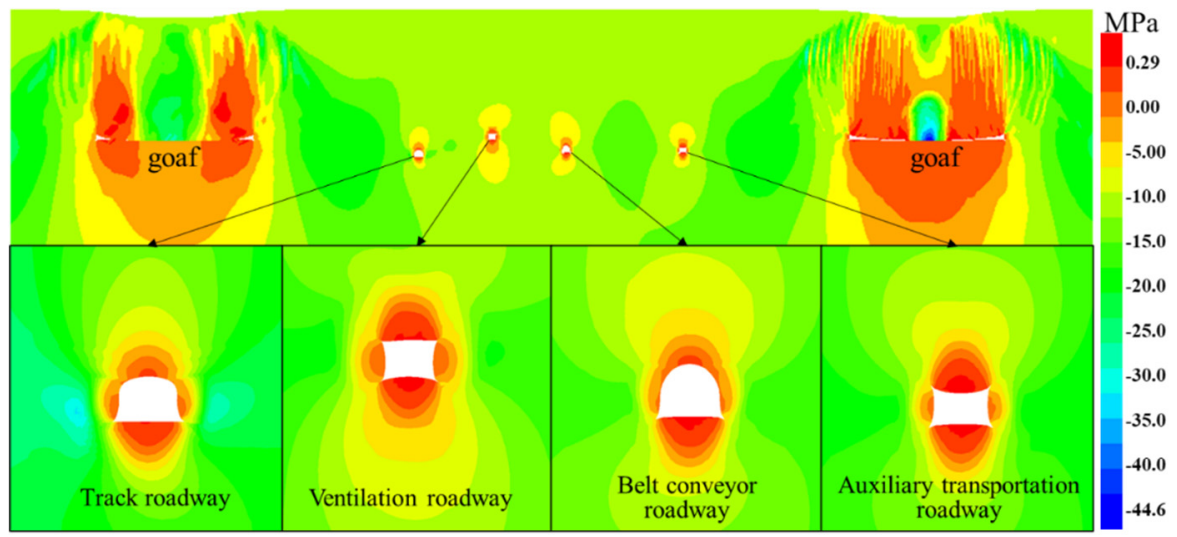

(a)

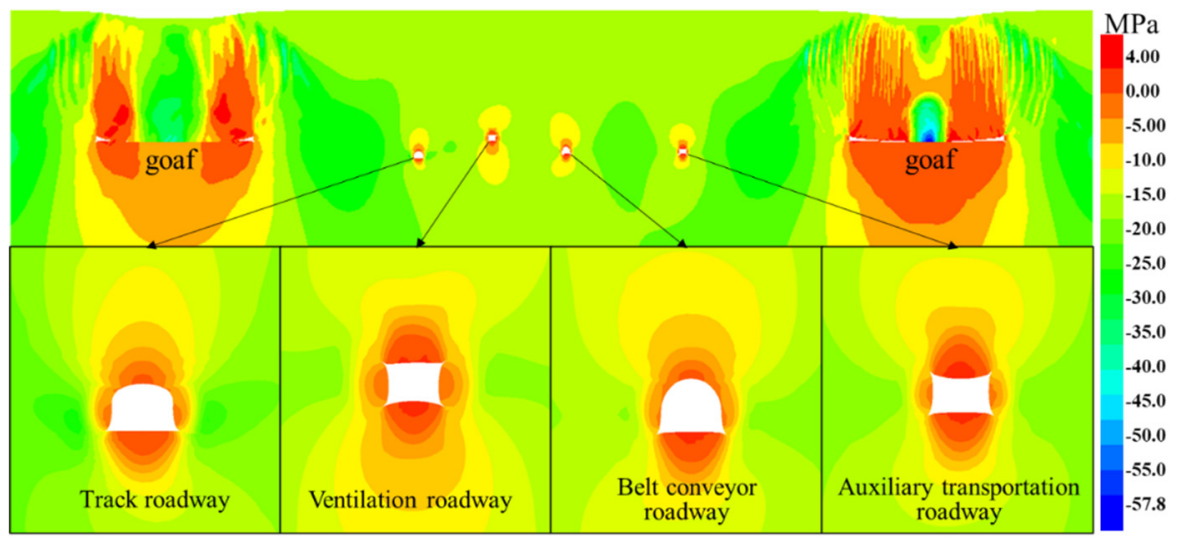

(b)

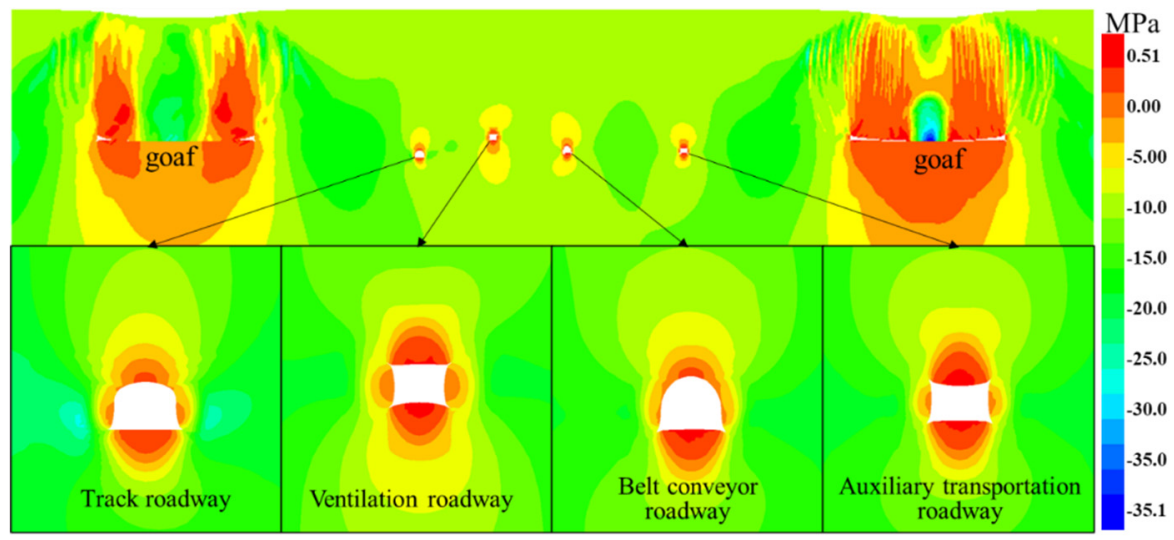

(c)

Figure 10. Vertical stress distribution of the different distances between working face and roadway. (a) The stop line is $50 \mathrm{~m}$ away from the roadway. (b) The stop line is $75 \mathrm{~m}$ away from the roadway. (c) The stop line is $100 \mathrm{~m}$ away from the roadway. 


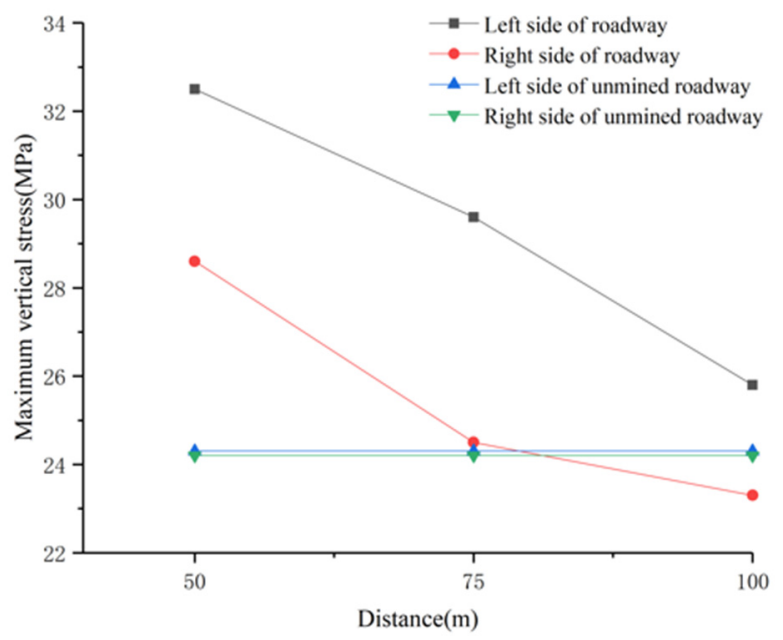

(a)

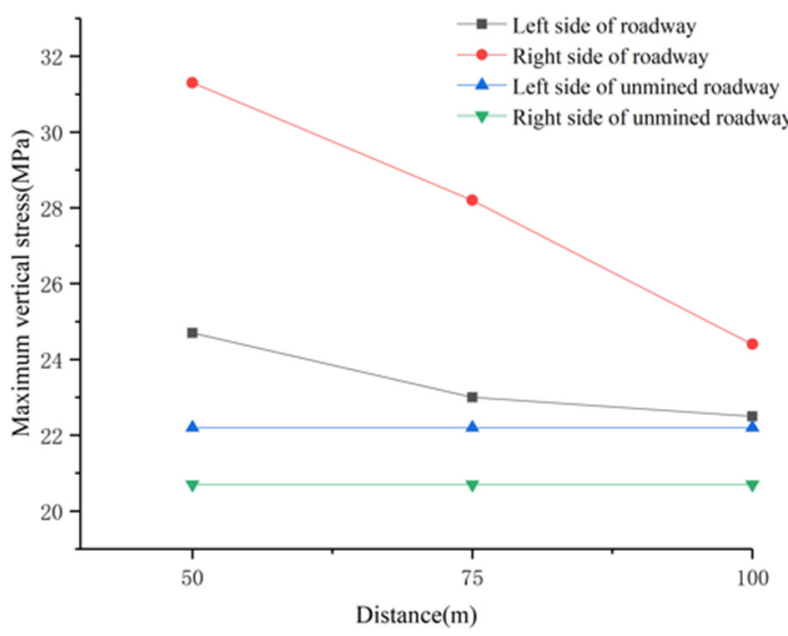

(b)

Figure 11. Maximum vertical stress at different distances between working face and roadway. (a) Maximum vertical stress at different locations from the track roadway. (b) Maximum vertical stress at different locations from the auxiliary transport roadway.

\subsection{The Influence of Working Face Rheological Coupling Mining on Deformation Disturbance of} Roadway Groups

The horizontal displacement distribution of the surrounding rock of the model roadway is shown in Figure 12, and the deformation of the two sides of the roadway changes with the rheological time, as shown in Figure 13. It can be seen from Figures 12 and 13 that the deformation of the two sides of the roadway groups increases with the increase in the rheological time. Within 0.2 years after the excavation of the roadway groups, the deformation first increased rapidly, and then tended to a stable rheological state. After the mining of the working face is completed, depending on the distance of the stop line, the roadway groups will be affected by different degrees of disturbance and rheology within a certain period, and they tend to a stable rheological state.

In the coal mining process of the working face, the track roadway and the auxiliary transport roadway are the closest to the working face, and they are also most affected by disturbance and rheology. When the mining stop line is $50 \mathrm{~m}$ and $75 \mathrm{~m}$, respectively, within 0.6 years after the mining of the working face, the track roadway and the auxiliary transport roadway will have accelerated rheology. The horizontal displacement of the 
roadway groups is rapidly increased by the impact of mining, and by when it reaches a stable rheological state.

When the stop line is $100 \mathrm{~m}$, the mining face has almost no effect on the roadway groups, and the roadway is always in a stable rheological state. When the mining stop line is $50 \mathrm{~m}$, the maximum deformation of the track main roadway is $1.22 \mathrm{~m}$, and the maximum deformation of the auxiliary transportation main roadway is $1.49 \mathrm{~m}$. When the mining stop line is $100 \mathrm{~m}$, the maximum deformation of the track main roadway is $0.98 \mathrm{~m}$, and the auxiliary transportation main roadway The maximum deformation is $1.26 \mathrm{~m}$.

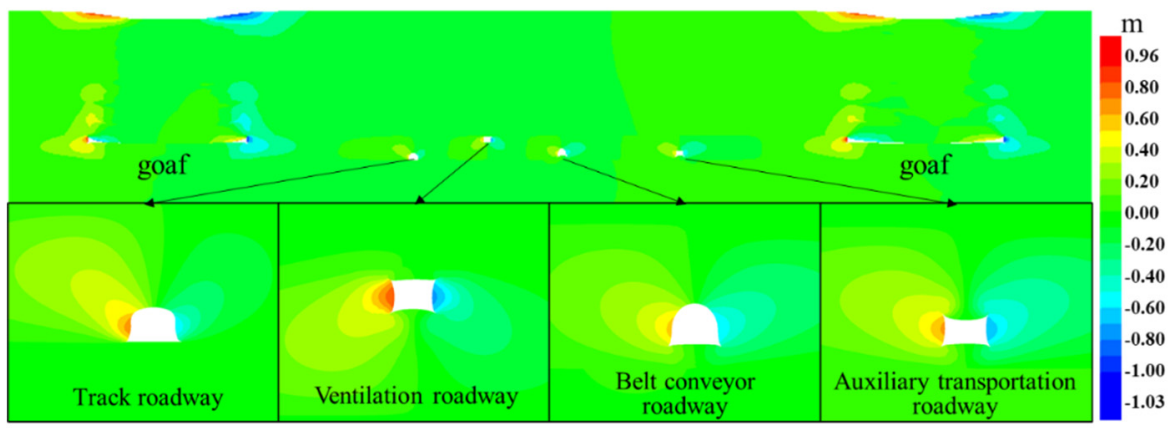

(a)

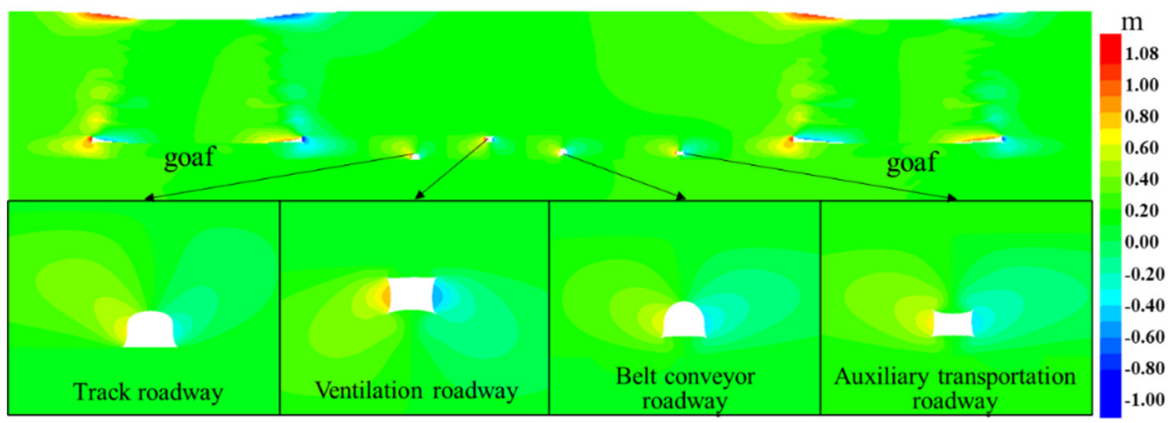

(b)

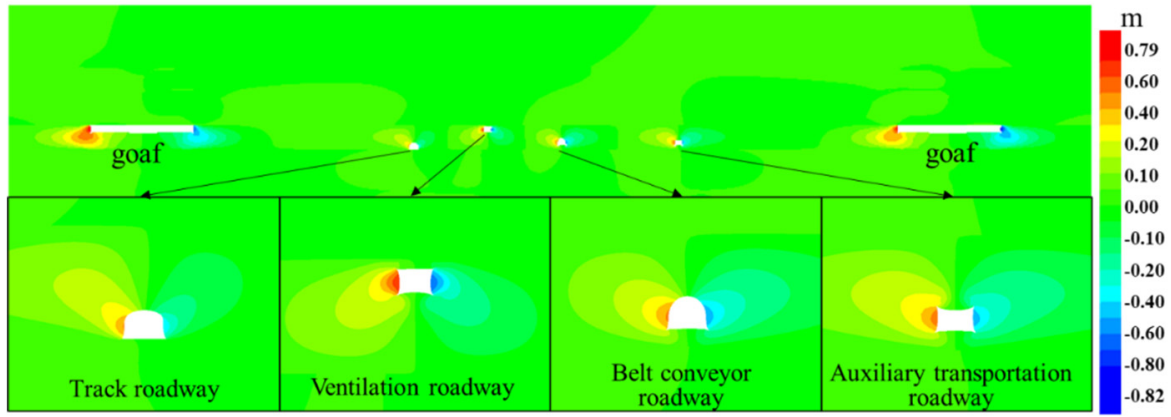

(c)

Figure 12. Cloud map of horizontal displacement distribution. (a) The stop line is $50 \mathrm{~m}$ away from the roadway. (b) The stop line is $75 \mathrm{~m}$ away from the roadway. (c) The stop line is $100 \mathrm{~m}$ away from the roadway. 


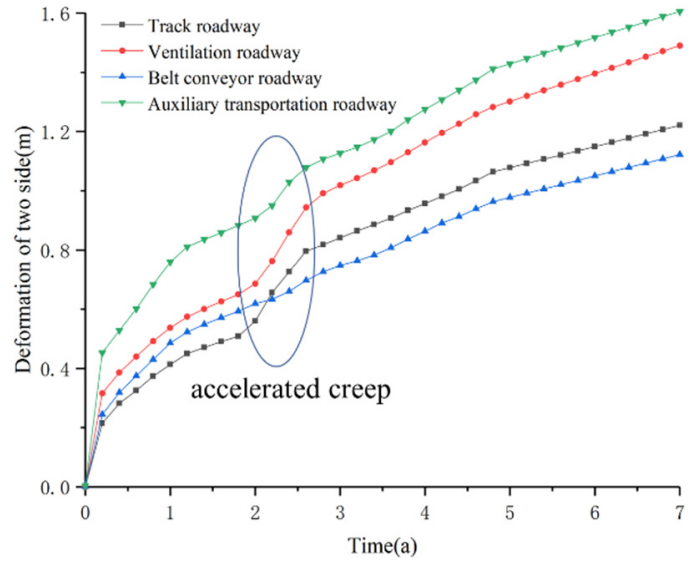

(a)

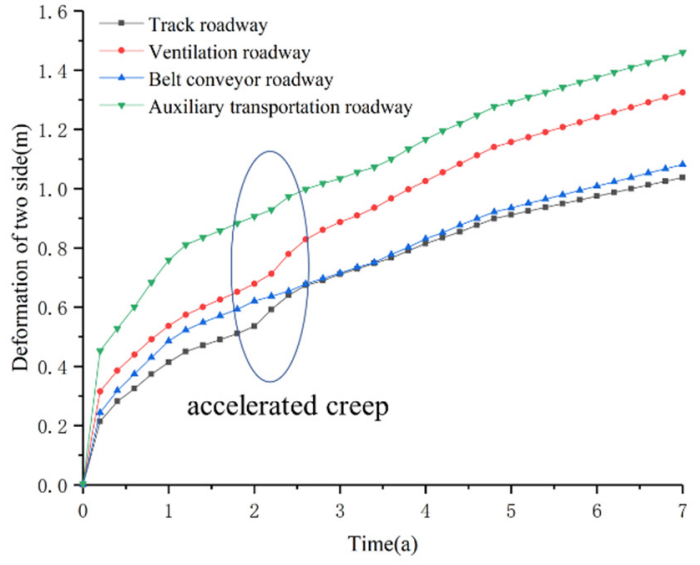

(b)

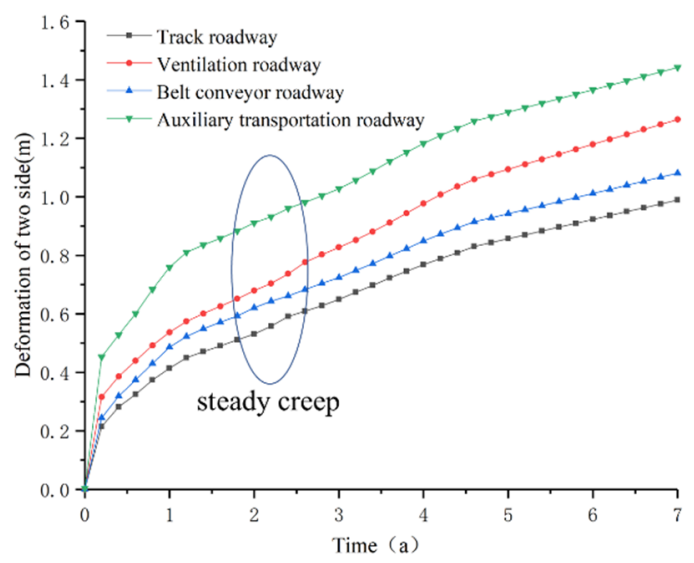

(c)

Figure 13. The deformation of the two sides of the roadway groups changed with the rheological time. (a) The stop line is $50 \mathrm{~m}$ away from the roadway. (b) The stop line is $75 \mathrm{~m}$ away from the roadway. (c) The stop line is $100 \mathrm{~m}$ away from the roadway.

The vertical displacement distribution of the surrounding rock of the model roadway is shown in Figure 14, and the deformation of the roof and floor of the roadway changes with the rheological time as shown in Figure 15. It can be seen from Figures 14 and 15 that the deformation trend of the roof and floor of the roadway is similar to that of the two gangs, and will not be repeated here.

When the mining stop line is $50 \mathrm{~m}$ and $75 \mathrm{~m}$, the roadway groups have an obvious accelerated rheological phenomenon within 0.6 years after mining at the working face, and then it enters a stable rheological state; when the mining stop line is $100 \mathrm{~m}$, the roadway is always stable rheological state. When the mining stop line is $50 \mathrm{~m}$, the maximum deformation of the track roadway is $0.96 \mathrm{~m}$, and the maximum deformation of the auxiliary transport roadway is $1.32 \mathrm{~m}$. When the mining stop line is $100 \mathrm{~m}$, the maximum deformation of the track roadway is $0.77 \mathrm{~m}$, and the maximum deformation of the auxiliary transport roadway is $1.06 \mathrm{~m}$.

From the above analysis, it can be seen that the stop line of $100 \mathrm{~m}$ is compared with the stop line of $50 \mathrm{~m}$. When the stop line is $100 \mathrm{~m}$, the maximum displacement of the two sides of the track roadway and the maximum displacement of the roof and floor are reduced by $20.0 \%$ and $18.8 \%$, respectively. The maximum displacement of the two sides of the auxiliary transport roadway and the maximum displacement of the roof and floor decreased by $15.4 \%$ and $19.7 \%$, respectively. Moreover, when the mining stop line is 100 $\mathrm{m}$, the roadway deformation has been in a stable rheological state, which proves that the 
roadway groups are not affected by mining. Therefore, the stop line of $100 \mathrm{~m}$ is beneficial to the long-term stability of the roadway.

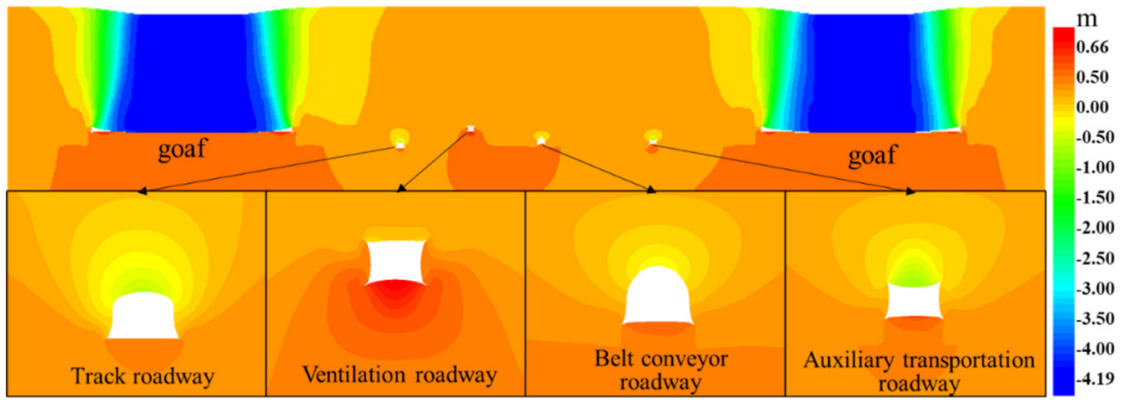

(a)

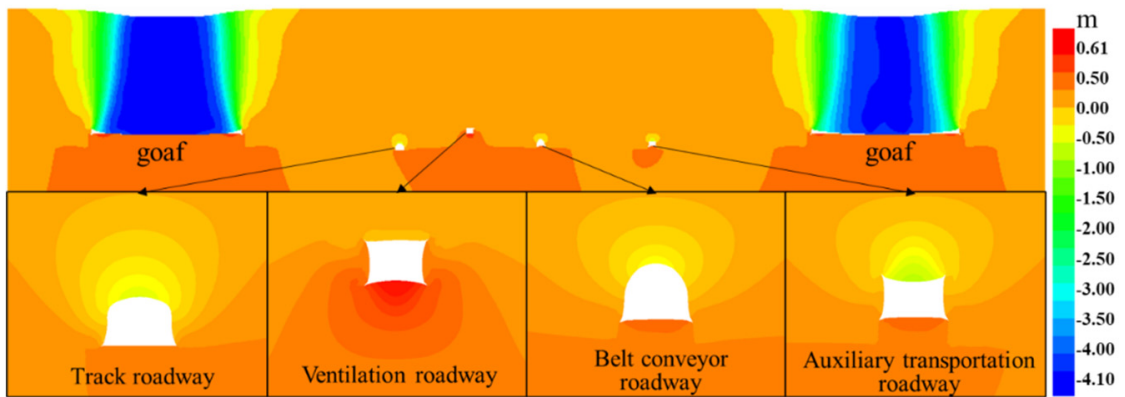

(b)

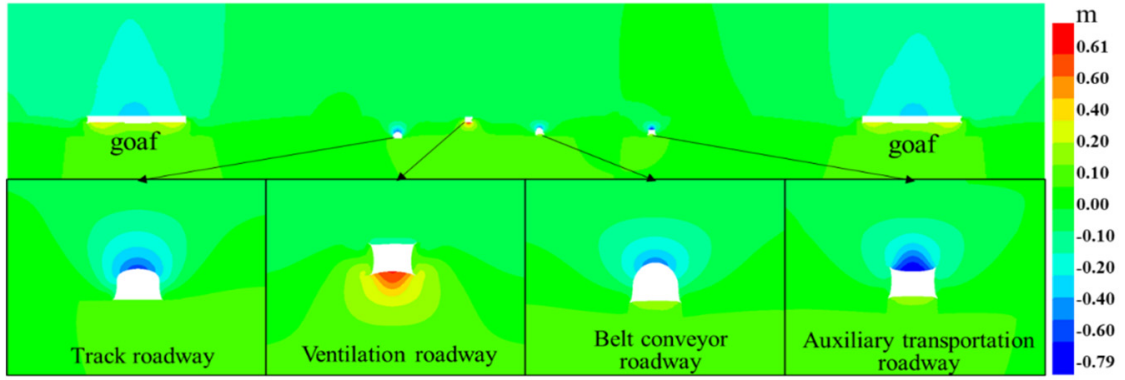

(c)

Figure 14. Cloud map of vertical displacement distribution. (a) The stop line is $50 \mathrm{~m}$ away from the roadway. (b) The stop line is $75 \mathrm{~m}$ away from the roadway. (c) The stop line is $100 \mathrm{~m}$ away from the roadway. 


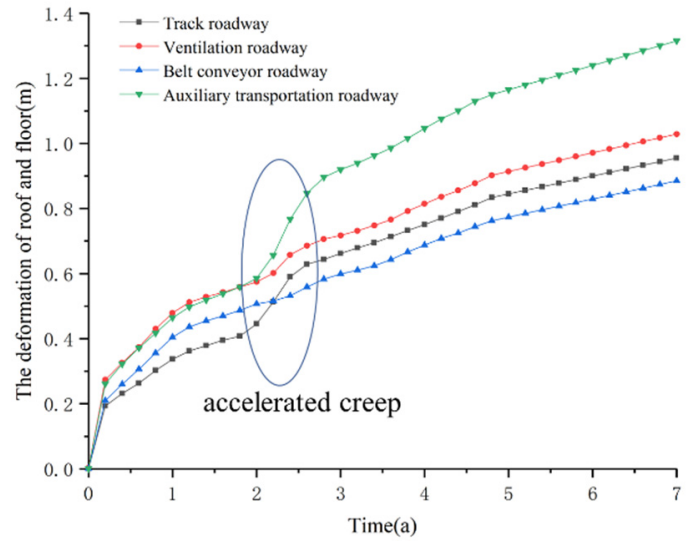

(a)

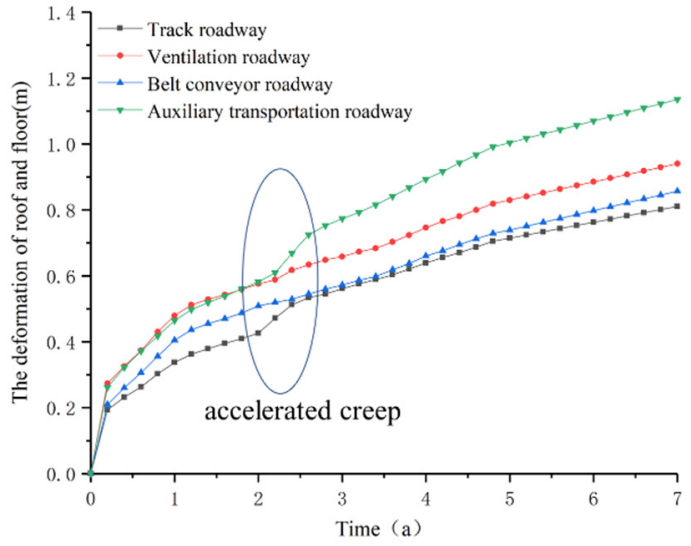

(b)

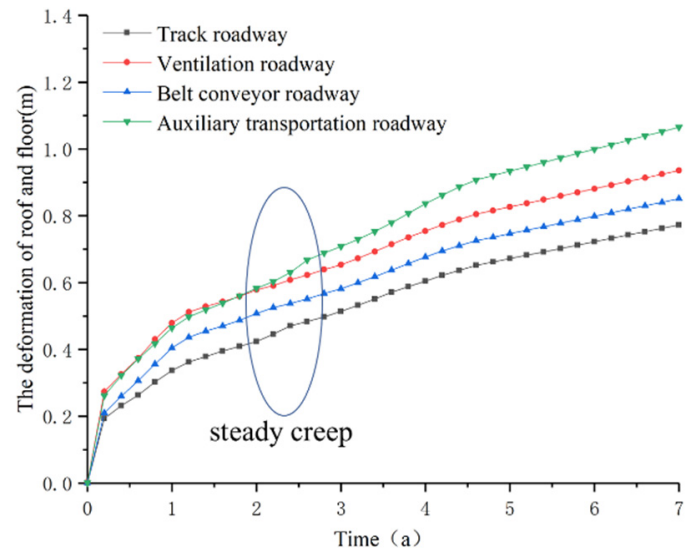

(c)

Figure 15. Variation of the roof and floor deformation of roadway groups with a rheological time. (a) The stop line is $50 \mathrm{~m}$ away from the roadway. (b) The stop line is $75 \mathrm{~m}$ away from the roadway. (c) The stop line is $100 \mathrm{~m}$ away from the roadway.

4.4. The Influence of Rheological Coupling Mining of Working Face on Disturbance of Plastic Zone of Roadway Groups

The plastic zone distribution of the surrounding rock of the model roadway is shown in Figure 16. Tables 3 and 4 show the expansion depth of the plastic zone of the roof and floor of the roadway and the two sides of the roadway under the conditions of different mining stop lines. It can be seen that after 5 years of rheological deformation of the roadway groups, the plastic areas of the four main roadways under different stop-line conditions have become larger than that when they were not mined. When the mining stop line is $50 \mathrm{~m}$, the plastic zone change of the four main roadways is the largest. When the stop line is $75 \mathrm{~m}$, the plastic area of the return airway and belt roadway will be less affected by the mining, while the plastic area of the track and auxiliary transportation roadway will change greatly.

When the mining stop line is $50 \mathrm{~m}$, the depth of the plastic zone has been expanded under the influence of long-term rheological deformation and mining. Compared with the time when the working face is not mined, the total expansion depth of the plastic zone of the roadway groups at this time has increased by $8.6 \%$. When the mining stop line is $100 \mathrm{~m}$, the disturbance to the roadway groups is very small, and the total expansion depth of the plastic zone of the roadway groups only increases by $3.5 \%$ compared with the case of no mining, and the roadway groups are hardly affected by mining. 


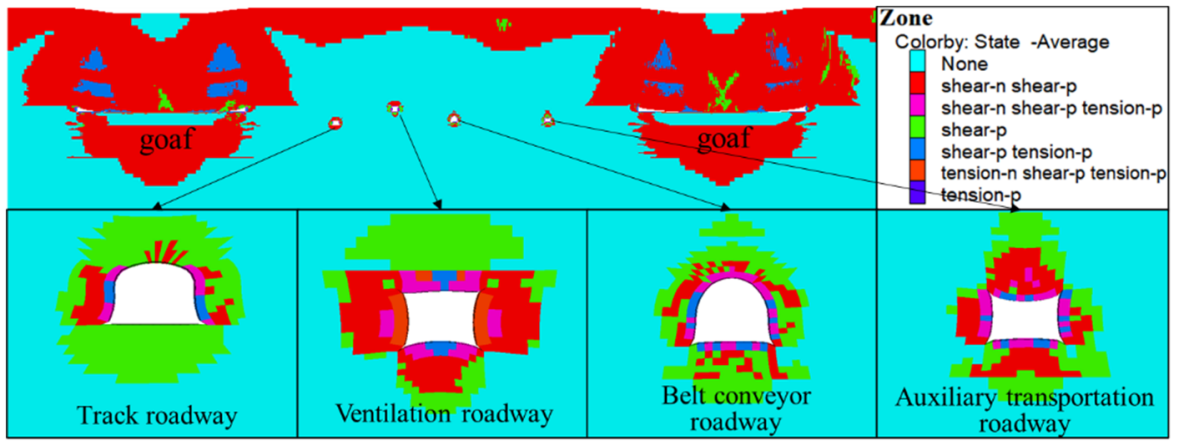

(a)

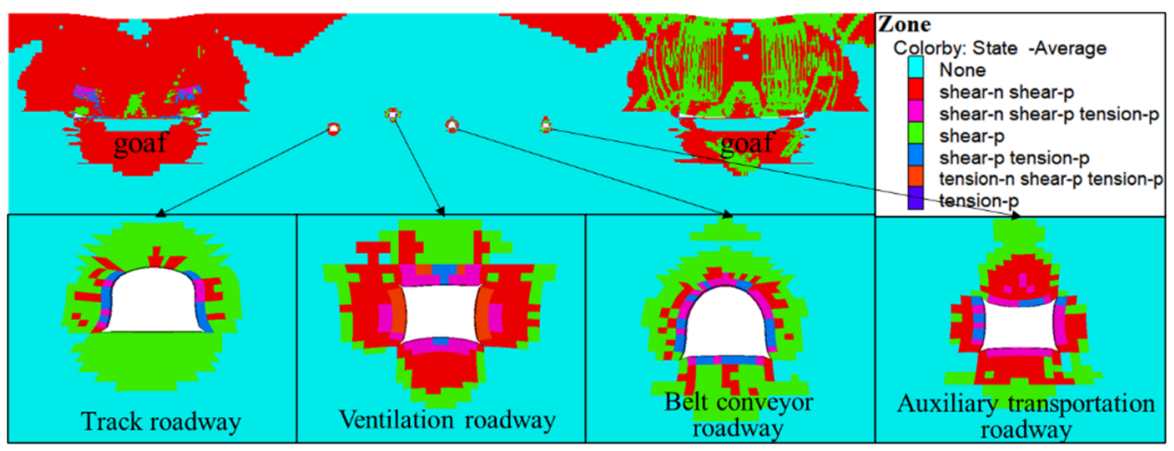

(b)

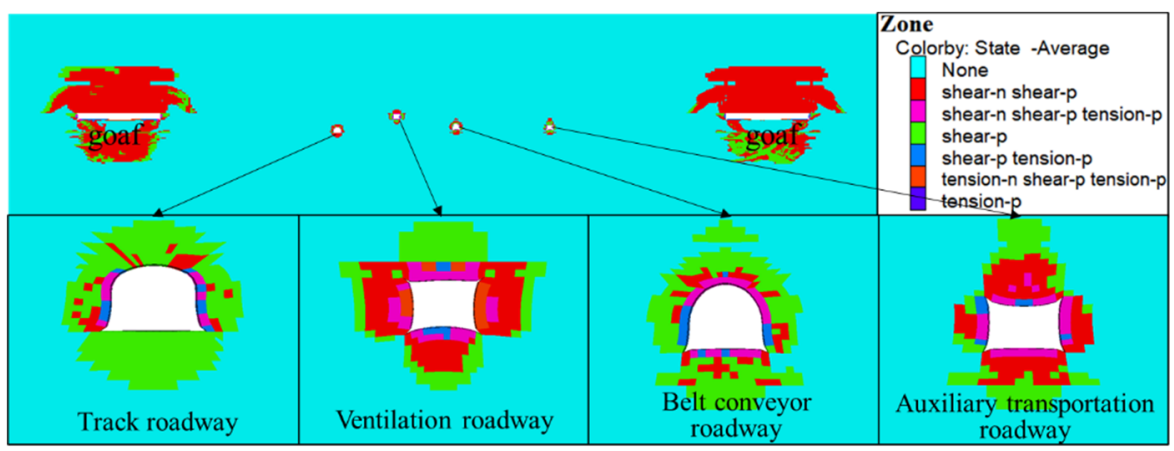

(c)

Figure 16. Distribution of plastic zone in the roadway. (a) The stop line is $50 \mathrm{~m}$ away from the roadway. (b) The stop line is $75 \mathrm{~m}$ away from the roadway. (c) The stop line is $100 \mathrm{~m}$ away from the roadway.

Table 3. The expansion depth of the roof and floor plastic zone.

\begin{tabular}{ccccc}
\hline & \multicolumn{4}{c}{ Expansion Depth } \\
\hline $\begin{array}{c}\text { Distance from } \\
\text { Stoping Line } \\
\text { /m }\end{array}$ & Track Roadway & $\begin{array}{c}\text { Ventilation } \\
\text { Roadway }\end{array}$ & $\begin{array}{c}\text { Belt Conveyor } \\
\text { Roadway }\end{array}$ & $\begin{array}{c}\text { Auxiliary } \\
\text { Transportation } \\
\text { Roadway }\end{array}$ \\
\hline Unmined & 4524 & 6026 & 6149 & 7234 \\
50 & 4718 & 6282 & 6391 & 7760 \\
75 & 4670 & 6211 & 6366 & 7569 \\
100 & 4655 & 6209 & 6373 & 7390 \\
\hline
\end{tabular}


Table 4. The expansion depth of the plastic zone of both sides.

\begin{tabular}{ccccc}
\hline & \multicolumn{4}{c}{ Expansion Depth } \\
\hline $\begin{array}{c}\text { Distance from } \\
\text { Stoping Line } \\
\text { /m }\end{array}$ & Track Roadway & $\begin{array}{c}\text { Ventilation } \\
\text { Roadway }\end{array}$ & $\begin{array}{c}\text { Belt Conveyor } \\
\text { Roadway }\end{array}$ & $\begin{array}{c}\text { Auxiliary } \\
\text { Transportation } \\
\text { Roadway }\end{array}$ \\
\hline $\begin{array}{c}\text { Unmined } \\
50\end{array}$ & 3839 & 6294 & 4097 & 3239 \\
75 & 4628 & 6345 & 4259 & 4578 \\
100 & 4108 & 6337 & 4244 & 3410 \\
\hline
\end{tabular}

In summary, when the stop line is $100 \mathrm{~m}$, the mining face has little effect on the stress distribution, displacement distribution, and plastic zone of the surrounding rock of the roadway. The key layer theory and the theory of surface subsidence can be verified. When the width of the coal pillar exceeds the subsidence range of the rock layer, it will not affect the roadway. Therefore, it can be considered that leaving coal pillars of more than $100 \mathrm{~m}$ is beneficial to the stability control of the surrounding rock of the roadway.

\section{Conclusions}

In order to study the influence of rheological coupling mining disturbance on roadway stability, through numerical simulation, first the roadway has undergone two years of rheology, and secondly, the research on the influence of mining coupling rheology on the roadway is carried out. The rheological time is 5 years. The deformation and plastic zone conditions of the roadway when the working face is mined to the position of $50 \mathrm{~m}, 75 \mathrm{~m}$ and $100 \mathrm{~m}$ from the roadway group, respectively, are analyzed. The following conclusions can be drawn from the present study.

(1) After two years of rheological deformation of the excavation roadway groups, there is a slight mutual disturbance among the track roadway, ventilation roadway, and belt conveyor roadway; there is no mutual disturbance between the belt conveyor roadway and auxiliary transport roadway.

(2) After the coal seam is mined, the maximum vertical stress on both sides of the roadway is increased. In the process of increasing the stop line from $50 \mathrm{~m}$ to $100 \mathrm{~m}$, the maximum vertical stress of the two sides of the track roadway and auxiliary transport roadway is gradually reduced. When the stop line is $100 \mathrm{~m}$, the change rate of the maximum vertical stress is the smallest.

(3) Mining at the working face mainly has a disturbing effect on the track roadway and auxiliary transport roadway. As the distance from the mining stop line increases, the amount of surrounding rock deformation of the roadway groups gradually decreases. When the mining stop line is $100 \mathrm{~m}$, mining has no obvious disturbing influence on the ventilation roadway and belt conveyor roadway, and the disturbance influence on the track roadway and auxiliary transport roadway is greatly reduced.

(4) The expansion depth of the plastic zone of the roadway groups decreases with the increase in the stop-mining line distance. When the stop-mining line distance is $100 \mathrm{~m}$, the total expansion depth of the plastic zone of the roadway groups only increases by $3.5 \%$ compared with the case of no mining, and the roadway groups are hardly affected by mining.

Author Contributions: Conceptualization, S.Y., G.L. and R.B.; methodology, B.Y.; investigation, R.F.; writing—original draft preparation, S.Y. and G.L.; writing—-review and editing, G.L., Y.S. and S.Y.; supervision, G.L.; funding acquisition, G.L. All authors have read and agreed to the published version of the manuscript.

Funding: This research was funded by the projects of "the Fundamental Research Funds for the Central Universities (2020ZDPY0221, 2021QN1003)", "National Natural Science Foundation of China (52104106, 52174089)”, “Basic Research Program of Xuzhou (KC21017)”. 
Institutional Review Board Statement: Not applicable.

Informed Consent Statement: Not applicable.

Data Availability Statement: The Microsoft Excel Worksheet data used to support the findings of this study are available from the corresponding author upon request.

Acknowledgments: The authors are grateful to Jining No. 2 Coal Mine, Yanzhou Coal Minging Co. Ltd. Special thanks to the reviewers' comments and editor's work.

Conflicts of Interest: The authors declare no conflict of interest.

\section{References}

1. Wang, Q.; Gao, H.; Yu, H.; Jiang, B.; Liu, B. Method for Measuring Rock Mass Characteristics and Evaluating the GroutingReinforced Effect Based on Digital Drilling. Rock Mech. Rock Eng. 2018, 52, 841-851. [CrossRef]

2. Sun, Y.; Li, G.; Zhang, J.; Xu, J. Failure Mechanisms of Rheological Coal Roadway. Sustainability 2020, 12, 2885. [CrossRef]

3. Xiao, C.; Zheng, H.; Hou, X.; Zhang, X. A stability study of goaf based on mechanical properties degradation of rock caused by rheological and disturbing loads. Int. J. Min. Sci. Technol. 2015, 25, 741-747. [CrossRef]

4. Jia, J.; Yu, F.; Tan, Y.; Gao, X.; Zhang, H. Experimental Investigations on Rheological Properties of Mudstone in Kilometer-Deep Mine. Adv. Civ. Eng. 2021, 2021, 6615379. [CrossRef]

5. Qu, G.L.; Wang, J.; Liu, G.L. Research on Supporting Theory of Pressure-Bearing Ring and Yield Supporting Technology in Extremely Soft Rock Roadway. Appl. Mech. Mater. 2013, 395, 536-543. [CrossRef]

6. Lin, H. Study of Soft Rock Roadway Support Technique. Procedia Eng. 2011, 26, 321-326. [CrossRef]

7. Li, C.L.; Li, Z.Y. Geology Analysis and Support Scheme Design in Soft Rock Coal Mine. Adv. Mater. Res. 2012, 446, 1591-1595. [CrossRef]

8. Ma, N.J.; Zhao, Z.Q.; Zhao, H.; Jiang, L.S. High Strength Combined Support Technology in Deep High Stress Soft Rock Roadway. Adv. Mater. Res. 2012, 524, 598-603. [CrossRef]

9. Li, S.C.; Wang, H.T.; Wang, Q.; Jiang, B.; Wang, F.Q.; Guo, N.B.; Liu, W.J.; Ren, Y.X. Failure mechanism of bolting support and high-strength bolt-grouting technology for deep and soft surrounding rock with high stress. J. Cent. South Univ. 2016, 23, 440-448. [CrossRef]

10. Sun, Y.; Li, G.; Zhang, J.; Qian, D. Stability Control for the Rheological Roadway by a Novel High-Efficiency Jet Grouting Technique in Deep Underground Coal Mines. Sustainability 2019, 11, 6494. [CrossRef]

11. Chen, Y.; Meng, Q.; Xu, G.; Wu, H.; Zhang, G. Bolt-grouting combined support technology in deep soft rock roadway. Int. J. Min. Sci. Technol. 2016, 26, 777-785. [CrossRef]

12. He, M.C.; Yand, J.; Qi, G.; Wang, S.R. Optimized design and its application of coupling support for soft rock roadway at great depth. J. Liaoning Tech. Univ. 2007, 1, 40-42.

13. $\mathrm{Li}$, J. The coal pillar design method for a deep mining roadway based on the shape of the plastic zone in surrounding rocks. Arab. J. Geosci. 2020, 13, 1-12. [CrossRef]

14. Yankai, R.C.L.K.Z. Study on Surrounding Rock Stability of Long-Span Coal Roadway under Influence of Mining and Support Technology Optimization. In Proceedings of the IOP Conference Series: Earth and Environmental Science, Hefei, China, 19-21 October 2018; p. 012016.

15. Zhai, C.; Xu, Y.; Xiang, X.; Yu, X.; Zou, Q.; Zhong, C. A novel active prevention technology for borehole instability under the influence of mining activities. J. Nat. Gas Sci. Eng. 2015, 27, 1585-1596. [CrossRef]

16. Zhan, Q.; Zheng, X.; Du, J.; Xiao, T. Coupling instability mechanism and joint control technology of soft-rock roadway with a buried depth of 1336 m. Rock Mech. Rock Eng. 2020, 53, 2233-2248. [CrossRef]

17. Li, G.; Sun, Y.; Zhang, J.; Zhang, Q.; Sun, C.; Zhang, S.; Bi, R. Experiment and application of coalcrete on roadway stability: A comparative analysis. Adv. Mater. Sci. Eng. 2020, 2020, 6813095. [CrossRef]

18. Sun, Y.; Li, G.; Zhang, J. Developing hybrid machine learning models for estimating the unconfined compressive strength of jet grouting composite: A comparative study. Appl. Sci. 2020, 10, 1612. [CrossRef]

19. Sun, Y.; Li, G.; Zhang, J. Investigation on jet grouting support strategy for controlling time-dependent deformation in the roadway. Energy Sci. Eng. 2020, 8, 2151-2158. [CrossRef]

20. Yu, W.; Pan, B.; Zhang, F.; Yao, S.; Liu, F. Deformation Characteristics and Determination of Optimum Supporting Time of Alteration Rock Mass in Deep Mine. KSCE J. Civ. Eng. 2019, 23, 4921-4932. [CrossRef]

21. Wu, K.; Shao, Z.; Qin, S.; Zhao, N.; Chu, Z. An improved non-linear creep model for rock applied to tunnel displacement prediction. Int. J. Appl. Mech. 2021. [CrossRef]

22. Bondarenko, V.; Hardygora, M.; Symanovych, H.; Sotskov, V.; Snihur, V. Numerical methods of geomechanics tasks solution during coal deposits' development. Min. Miner. Depos. 2016, 10, 1-12. [CrossRef]

23. Pongpanya, P.; Sasaoka, T.; Shimada, H.; Hamanaka, A.; Wahyudi, S. Numerical study on effect of longwall mining on stability of main roadway under weak ground conditions in Indonesia. J. Geol. Resour. Eng. 2017, 3, 93-104.

24. Trigueros, E.; Cánovas, M.; Arzúa, J.; Alcaraz, M. Stability of an abandoned siderite mine: A case study in northern Spain. Open Geosci. 2021, 13, 359-376. [CrossRef] 
25. Sun, Y.; Li, G.; Zhang, J.; Huang, J. Rockburst intensity evaluation by a novel systematic and evolved approach: Machine learning booster and application. Bull. Eng. Geol. Environ. 2021, 80, 8385-8395. [CrossRef]

26. Eremenko, V.A.; Galchenko, Y.P.; Kosyreva, M.A. Effect of Mining Geometry on Natural Stress Field in Underground Ore Mining with Conventional and Nature-Like Technologies. J. Min. Sci. 2020, 56, 416-425. [CrossRef]

27. Wen, Z.; Qu, G.; Wen, J.; Shi, Y.; Jia, C. Deformation failure characteristics of coal body and mining induced stress evolution law. Sci. World J. 2014, 2014, 714507. [CrossRef] [PubMed]

28. Wang, H.; Jiang, Y.; Xue, S.; Shen, B.; Wang, C.; Lv, J.; Yang, T. Assessment of excavation damaged zone around roadways under dynamic pressure induced by an active mining process. Int. J. Rock Mech. Min. Sci. 2015, 77, 265-277. [CrossRef]

29. Wang, H.; Shi, R.; Lu, C.; Jiang, Y.; Deng, D.; Zhang, D. Investigation of sudden faults instability induced by coal mining. Saf. Sci. 2019, 115, 256-264. [CrossRef]

30. Zhu, D.; Tu, S.; Tu, H.; Yang, Z. Mechanisms of support failure and prevention measures under double-layer room mining gobs-A case study: Shigetai coal mine. Int. J. Min. Sci. Technol. 2019, 29, 955-962. [CrossRef]

31. Wang, F.; Xu, J.; Xie, J.; Li, Z.; Guo, J. Mechanisms influencing the lateral roof roadway deformation by mining-induced fault population activation: A case study. Int. J. Oil Gas Coal Technol. 2016, 11, 411-428. [CrossRef]

32. Wang, Q.; He, M.; Li, S.; Jiang, Z.; Wang, Y.; Qin, Q.; Jiang, B. Comparative study of model tests on automatically formed roadway and gob-side entry driving in deep coal mines. Int. J. Min. Sci. Technol. 2021, 31, 591-601. [CrossRef]

33. Li, G.; Ma, F.; Guo, J.; Zhao, H.; Liu, G. Study on deformation failure mechanism and support technology of deep soft rock roadway. Eng. Geol. 2020, 264, 105262. [CrossRef]

34. Sun, Y.; Li, G.; Zhang, J.; Sun, J.; Huang, J.; Taherdangkoo, R. New Insights of Grouting in Coal Mass: From Small-Scale Experiments to Microstructures. Sustainability 2021, 13, 9315. [CrossRef]

35. Sun, Y.; Zhang, J.; Li, G.; Wang, Y.; Sun, J.; Jiang, C. Optimized neural network using beetle antennae search for predicting the unconfined compressive strength of jet grouting coalcretes. Int. J. Numer. Anal. Methods Geomech. 2019, 43, 801-813. [CrossRef]

36. Doan, D.V.; Zhao, H.C.; Cao, J.; Yong, C.; Meng, W. Control technology for soft rock roadway in inclined coal seam: A case study in Nui Beo mine, Quang Ninh, Vietnam. Int. J. 2018, 14, 175-182. [CrossRef]

37. Piotr, M.; Łukasz, O.; Piotr, B. Modelling the small throw fault effect on the stability of a mining roadway and its verification by in situ investigation. Energies 2017, 10, 2082. [CrossRef]

38. Shiliang, L.; Caigen, W. Strata pressure law for roadway in soft rocks and relationship between support and surrounding rock. In Geotechnical Instrumentation and Monitoring in Open Pit and Underground Mining; CRC Press: Boca Raton, FL, USA, 2020; pp. 339-344.

39. Xie, S.; Pan, H.; Zeng, J.; Wang, E.; Chen, D.; Zhang, T.; Peng, X.; Yang, J.; Chen, F.; Qiao, S. A case study on control technology of surrounding rock of a large section chamber under a 1200-m deep goaf in Xingdong coal mine, China. Eng. Fail. Anal. 2019, 104, 112-125. [CrossRef]

40. Wang, H.; Zheng, P.Q.; Zhao, W.J.; Tian, H.M. Application of a combined supporting technology with U-shaped steel support and anchor-grouting to surrounding soft rock reinforcement in roadway. J. Cent. South Univ. 2018, 25, 1240-1250. [CrossRef]

41. Chakravarthi, S.S.; Kassam, A.B.; Fukui, M.B.; Monroy-Sosa, A.; Rothong, N.; Cunningham, J.; Jennings, J.E.; Guenther, N.; Connelly, J.; Kaemmerer, T.; et al. Awake Surgical Management of Third Ventricular Tumors: A Preliminary Safety, Feasibility, and Clinical Applications Study. Geofluids 2019, 17, 208-226. [CrossRef] 